\title{
Fournier's gangrene: Review of 120 patients and predictors of mortality
}

\author{
Tuncay Yılmazlar, M.D.,' Özgen Işık, M.D., ${ }^{1}$ Ersin Öztürk, M.D., ${ }^{1}$ \\ Ali Özer, M.D., ${ }^{1}$ Barış Gülcü, M.D., ${ }^{1}$ İlker Ercan, M.D. ${ }^{2}$
}

1'Department of General Surgery, Uludag University Faculty of Medicine, Bursa;

${ }^{2}$ Department of Biostatistics, Uludag University Faculty of Medicine, Bursa

\begin{abstract}
BACKGROUND: Fournier's gangrene (FG) is a devastating and potentially fatal disease requiring prompt and aggressive debridement. In this study, it was aimed to assess the predictors of mortality in a large cohort.

METHODS: Prospectively maintained data of patients with FG were analyzed. Demographic data, duration of symptoms, Uludag Fournier's Gangrene Severity Index (UFGSI) scores, co-morbidities [particularly diabetes mellitus (DM)], etiologies, number of debridement, stoma requirements, length of intensive care unit and hospital stay, and morbidity and mortality rates were reviewed. Multivariate analysis was performed in order to determine factors affecting mortality.

RESULTS: 120 patients (8I males) were included in the study. Median age was 58 (22-85) years. UFGSI score was median 9 (I-30). DM was present in 69 (57.5\%) patients. Etiology of FG was perianal in fifty-nine, urogenital in 52, and skin in 9 patients. Median debridement count was $3(\mathrm{I}-12)$. Thirty-one patients required stoma. Forty-eight patients were admitted to intensive care unit and 25 patients required mechanical ventilation. Overall mortality rate was $20.8 \%$. Multivariate analysis revealed UFGSI as the only predictor of mortality $(p=0.001)$. Mortality rate was 13.64 times higher for patients with a UFGSI score of 9 or higher.
\end{abstract}

CONCLUSION: Fournier's gangrene is a mortal disease requiring emergency surgery. UFGSI is an efficient predictor of mortality for patients with FG.

Key words: Fournier's gangrene; mortality; severity score.

\section{INTRODUCTION}

Fournier's gangrene (FG) is progressive and, if inadequately treated, mortal, necrotizing fasciitis of perineal, perianal, and genital region requiring emergency surgery. ${ }^{[1-3]}$ These infections are typically polymicrobial, with both aerobic and anaerobic organisms present in the majority of cases. ${ }^{[3,4]}$ In spite of the widely varying microorganisms in the etiology, its treatment is unique for all cases including emergency removal of the devitalized tissues, adequate resuscitation, and intravenous (iv) administration of wide-spectrum antibiotics. ${ }^{[1-7]}$

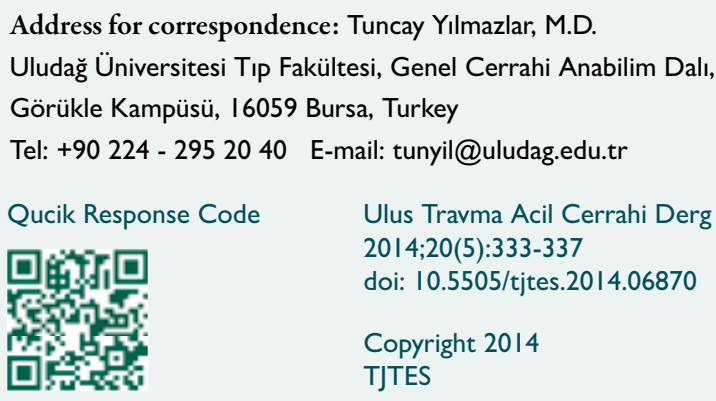

FG affects both males and females regardless of age. Underlying colorectal or urological diseases and diabetes mellitus (DM) are common among patients with FG. ${ }^{[3]}$ However, mortality of FG varies from 3 to $45 \%$, even if it is well managed. ${ }^{[3,8-11]}$ Factors affecting the outcomes are patient, disease, and surgeon related. ${ }^{[2]}$ There are several scoring systems for predicting the risk of mortality of FG. Acute Physiology and Chronic Health Evaluation (APACHE) II scoring system is a commonly used method for predicting outcomes of critically ill patients with necrotizing soft tissue infection (NSTI). ${ }^{[12]}$ Another well-defined method, which is also disease specific, is Fournier's Gangrene Severity Index (FGSI). ${ }^{[13]}$ Uludag Fournier's Gangrene Severity Index (UFGSI) is a novel scoring system established by our department previously. ${ }^{[2]}$

In this study, it was aimed to present the largest single institute serial of FG and determine the risk factors associated with mortality.

\section{MATERIALS AND METHODS}

Data of the patients who underwent emergency debridement for FG between 1996 and 2012 were extracted from the pro- 
spectively maintained departmental FG database. Only adult patients admitted or referred to our department and diagnosed with FG were included in the study. FG is defined as NSTI of perianal, perineal and genital region.

All patients underwent at least one radical debridement of affected devitalized tissues within 12 hours after admission. Iv. third-generation cephalosporin and metronidazole antibiotherapy was started at the emergency room and continued. Empiric antibiotherapy was changed according to the results of the microbiological analysis of the removed tissue samples in the first debridement, if necessary. Conventional wound dressings were changed daily and wound exploration was performed in the operating room every 48 hours until healthy granulation tissue was formed in the wound. Vacuum assisted closure (VAC; Kinetic Concepts, Inc., San Antonio, TX) in wound management of FG patients have been widely used by us for the last five years. Dressings were changed, and wound exploration was performed every 72 hours in the operating room for patients whose wounds were managed with VAC therapy. Patients underwent additional debridements, if necessary, during their wound explorations. Debridements continued until the removal of all necrotic tissues and the establishment of healthy granulation tissue in the wound. Patients with severe sepsis, requiring vasopressors or mechanical ventilation support were treated in the intensive care unit (ICU). Patients who were not stable enough to transfer from the ICU were debrided at the bedside. Skin defects, which were not convenient for staged tertiary closure, were reconstructed with split thickness skin graft (STSG).

Patient demographics, duration of symptoms, co-morbidities, presence of DM, etiology of NSTI, direct admission or referral from peripheral centers, APACHE II score, FGSI score, UFGSI score, debridement counts, anesthesia type (general or regional), stoma requirement, microbiological analysis results, need of mechanical ventilation, wound closure type, length of hospital and ICU stay were recorded.

Descriptive statistical methods were employed to evaluate clinical characteristics, management, and outcome. Data presented as median and ranges. Multivariate logistic regression analysis was performed to determine independent risk factors associated with mortality. Statistical Package for Social Sciences (SPSS) ver. 16.0 was used for performing statistical analysis.

\section{RESULTS}

One hundred and twenty patients ( 81 males), with a median age of 58 (range, 22-85) were included in the study. Ninety-five of the 120 patients survived and the mortality rate was $20.8 \%$. Twelve of the non-survivors were female. Most common cause of death was the multi-organ failure due to septic shock in fourteen patients. Pneumonia $(n=5)$, cardio- genic shock $(n=4)$ and end-stage carcinoma $(n=2)$ were other mortality causes.

Median duration of symptoms (from the onset of the symptoms to arrival at our hospital) was median seven days ( I-40). Mortality rate was $27 \%$ among patients with symptom duration longer than seven days. Forty patients (33\%) were admitted primarily to our emergency department while others $(67 \%)$ were referred from peripheral centers. Sixty-nine patients had DM and 31 patients had no other co-morbidities.

While the etiology of FG was anorectal diseases in fifty-nine patients $(49.2 \%)$, other sources were urogenital diseases (43.3\%) and skin infections (7.5\%). No microorganisms were isolated in ten patients. The most common pathogen was $E$. Coli in seventy-four patients. Enterococci, Streptococci, Staphylococci, Klebsiella, Pseudomonas and Proteus were other microorganisms isolated in wound cultures, consecutively. None of the three patients with fungi survived. Microbiological analysis results of thirty-six patients could not be documented. Anaerobic culture could not be performed in our hospital because of technical difficulties.

Wound management was performed with VAC therapy in forty-two patients. Median debridement count was three $(I-I 2)$. Majority of the debridements were performed under spinoepidural anesthesia; however, twenty-seven patients (22.5\%) required general anesthesia. Fecal diversion with a temporary colostomy was established in thirty-one patients (25.8\%).

Forty-eight patients were treated in the intensive care unit (ICU) with a median of eight days ( I-40) length of stay. Twenty-five patients developed respiratory failure requiring mechanical ventilation. Mechanical ventilation treatment need was seven days (I-25). Mortality rate for patients requiring mechanical ventilation support was $68 \%$.

Wounds of seventy-five patients were suitable for staged tertiary closure. On the other hand, the wounds of forty-five patients were reconstructed with split thickness skin graft (STSG). Length of hospital stay was 14.5 days (2-65) for all patients.

Median UFGSI score was 9 (I-30) for all patients. Twentythree of 63 patients $(36.5 \%)$ with a UFGSI score $\geq 9$ did not survive. Median APACHE II and FGSI scores were 9 (0-3I) and 5 (0-23) respectively. In logistic regression analysis, only UFGSI score $\geq 9$ was detected as a significant predictor of mortality ( $p=0.00$ I, OR: 13.64, Cl: 2.874-64.802). Logistic regression analysis results are shown in Table $\mathrm{I}$.

\section{DISCUSSION}

In spite of the developing medical technology and experience, FG is still a fatal disease. A mortality rate of $20.8 \%$ was 
Table I. Logistic regression analysis results for mortality predictors of Fournier's gangrene

\begin{tabular}{lcccc}
\hline Factors & P value & Odd's Ratio & \multicolumn{2}{c}{$95 \%$ Confidence Interval } \\
\hline & & & Lower & Upper \\
Gender & 0.45 & 1.53 & 0.502 & 4.683 \\
Symptom duration & 0.13 & 1.09 & 0.976 & 1.215 \\
DMT & 0.43 & 1.55 & 0.521 & 4.623 \\
Etiology & & & & \\
$\quad$ Anorectal & 0.79 & 1.18 & 0.353 & 3.963 \\
$\quad$ Urogenital & 0.84 & 0.84 & 0.154 & 4.591 \\
$\quad$ Skin-based & $>0.99$ & Not estimated & - & - \\
Stoma & 0.42 & 1.68 & 0.478 & 5.921 \\
Debridement count & 0.89 & 1.02 & 0.789 & 1.316 \\
UFGSIs score $\geq 9$ & $0.00 I^{*}$ & 13.64 & 2.874 & 64.802 \\
\hline
\end{tabular}

I Diabetes Mellitus, § Uludag Fournier's gangrene severity index.

detected in our tertiary and experienced center. Accurate estimation of the risk of mortality can help patients and their physicians to manage treatment process and expectations. There are several methods of mortality prediction including APACHE II score and FGSI which are commonly used traditional scoring systems. On the other hand, UFGSI is a novel and powerful predictor of mortality associated with FG. ${ }^{[2]}$

Impact of gender on the mortality risk has been previously investigated in several studies. Female pelvic anatomy has been claimed to be better for drainage of secretions through the vagina. ${ }^{[14]}$ According to this theory, it has been thought that FG is more frequent in the male gender. On the other hand, Czymek et al. reported that female gender was a risk factor for increased mortality. Mortality rate was $50 \%$ for female patients while it was $7.7 \%$ for male patients in their study. They suggested that female pelvic anatomy was a disadvantage related with rapid dissemination of the disease. ${ }^{[15]}$ In our serial, mortality rate for female patients was $30.8 \%$ compared to $16 \%$ in male patients. Although the mortality rate was double for female patients, female gender was not detected as a risk factor for mortality $(p=0.454)$.

Early diagnosis was reported to be associated with better outcomes in FG. ${ }^{[1,16-18]}$ A study including 379 patients identified from a nationwide database has suggested that early surgical treatment within two days after admission reduces mortality of FG. ${ }^{\left[{ }^{17]}\right.}$ Also, the interval time between the onset of symptoms and initial debridement has been reported to be a major predictor of mortality. ${ }^{[18]}$ Symptom duration was median seven days ( $1-40)$ in our study. Mortality rate was $27 \%$ for patients with symptom duration higher than seven days. A lower mortality rate (18\%) was detected in patients with symptom duration of seven days or fewer. However, we failed to determine symptom duration as a risk factor $(p=0.126)$.
More than half of all patients (57.5\%), and $68 \%$ of non-survivors had DM in our serial. There are several studies showing $D M$ as a risk factor for patients with FG. ${ }^{[1,3,6,7]}$ Nevertheless, there are also some studies where DM has been reported as one of the most frequent comorbidities in patients with FG although not influencing outcomes. ${ }^{[8-11,16,19]}$ Although it was the most common co-morbidity among all patients, DM was not determined as a risk factor for mortality $(p=0.429)$.

The most common origin of the FG was anorectal diseases (49.2\%) in our study, followed by urogenital diseases and skin infections. Since it is not always possible to determine the exact origin of the disease, FG may be treated by general surgeons and urologists, as well. There are two previous studies from general surgery departments reporting perianal abscess as the most common etiological factor. ${ }^{[10,16]}$ As a general surgery department, we have also observed anorectal-originated cases more frequently. However, a significant impact of etiology on the mortality rate has not been detected.

Fecal diversion was needed in thirty-one patients (25.8\%), and median debridement count was three $(1-12)$ in the present study. We previously reported a $41 \%$ fecal diversion rate in 2010 and fecal diversion was established to be related with higher costs and morbidity rates. ${ }^{[20]}$ In our current practice, we apply enemas routinely before changing the VAC dressings and change VAC dressings every 72 hours. VAC therapy offers fewer dressing changes, less pain, and similar costs comparing to conventional wound dressings in the management of FG patients. ${ }^{[2]}$ Therefore, wounds can be kept clean, be healed rapidly, and diversion requirement and debridement count can be reduced. Reduced fecal diversion rate in the present study comparing to our previous study is associated with increased utilization of VAC therapy, well-management of cases, and increased experience. However, both fecal di- 
version requirement and debridement count were not shown as a risk factor for mortality.

FGSI is a scoring system first described by Laor et al. in 1995. ${ }^{[13]}$ It is a physiological and metabolic status based scoring system. There are several studies validating the accuracy of FGSI and determining it as a predictor of mortality. ${ }^{[16,22]}$ We first described UFGSI in 2010 as a novel scoring system that can be used for predicting mortality in patients with FG. Determined threshold score for UFGSI was 9. It is a powerful scoring system combining age and disease dissemination with FGSI score and has a sensitivity of $94 \%$ and specificity of $81 \%{ }^{[2]}$

There is a recent study comparing FGSI, UFGSI, age-adjusted Charlson Comorbidity Index (ACCl) and Surgical APGAR (sAPGAR) scoring systems for FG. ${ }^{[23]}$ Although all four scoring systems have been claimed to be useful for mortality prediction, it has been suggested that scores can be easily calculated using ACCI and sAPGAR. Nevertheless, the highest sensitivity rate (85\%) was detected for UFGSI comparing to other scoring systems despite the low patient volume of the study. In this study, UFGSI was determined as a mortality predictor in multivariate analysis $(p=0.001)$. Patients with a UFGSI score $\geq 9$ were 13.64 times likely to develop mortality. Although risk factors affecting mortality in Fournier's Gangrene were assessed from prospectively collected data of the largest single center cohort, there may be a selection bias since our hospital is a tertiary referral center. However, large sample size gives this research its clinical value.

To the best of our knowledge, this is the largest single center serial reported in the literature. We also had the opportunity of validating the UFGSI scoring system in this large cohort. Depending on this scoring system, we can say that patients with wide disease dissemination and older than 60 years of age are in a high-risk group. Since mortality is the major problem for this devastating disease, extra attention is required for the management of the patients in high-risk group.

Conflict of interest: None declared.

\section{REFERENCES}

1. Aridogan IA, Izol V, Abat D, Karsli O, Bayazit Y, Satar N. Epidemiological characteristics of Fournier's gangrene: a report of 71 patients. Urol Int 2012;89:457-61. CrossRef

2. Yilmazlar T, Ozturk E, Ozguc H, Ercan I, Vuruskan H, Oktay B. Fournier's gangrene: an analysis of 80 patients and a novel scoring system. Tech Coloproctol 2010;14:217-23. CrossRef

3. Eke N. Fournier's gangrene: a review of 1726 cases. Br J Surg 2000;87:718-28. CrossRef

4. Bjurlin MA, O'Grady T, Kim DY, Divakaruni N, Drago A, Blumetti J, et al. Causative pathogens, antibiotic sensitivity, resistance patterns, and severity in a contemporary series of Fournier's gangrene. Urology 2013;81:752-8. CrossRef

5. Bhatnagar AM, Mohite PN, Suthar M. Fournier's gangrene: a review of
110 cases for aetiology, predisposing conditions, microorganisms, and modalities for coverage of necrosed scrotum with bare testes. N Z Med J 2008;121:46-56.

6. Yanar H, Taviloglu K, Ertekin C, Guloglu R, Zorba U, Cabioglu N, et al. Fournier's gangrene: risk factors and strategies for management. World $\mathrm{J}$ Surg 2006;30:1750-4. CrossRef

7. Martinschek A, Evers B, Lampl L, Gerngroß H, Schmidt R, Sparwasser $C$. Prognostic aspects, survival rate, and predisposing risk factors in patients with Fournier's gangrene and necrotizing soft tissue infections: evaluation of clinical outcome of 55 patients. Urol Int 2012;89:173-9.

8. Erol B, Tuncel A, Hanci V, Tokgoz H, Yildiz A, Akduman B, et al. Fournier's gangrene: overview of prognostic factors and definition of new prognostic parameter. Urology 2010;75:1193-8. CrossRef

9. Ruiz-Tovar J, Córdoba L, Devesa JM. Prognostic factors in Fournier gangrene. Asian J Surg. 2012;35:37-41. CrossRef

10. Ersoz F, Sari S, Arikan S, Altiok M, Bektas H, Adas G, et al. Factors affecting mortality in Fournier's gangrene: experience with fifty-two patients. Singapore Med J 2012;53:537-40.

11. Benjelloun el B, Souiki T, Yakla N, Ousadden A, Mazaz K, Louchi A, et al. Fournier's gangrene: our experience with 50 patients and analysis of factors affecting mortality. World J Emerg Surg 2013;8:13. CrossRef

12. Yilmazlar T, Ozturk E, Alsoy A, Ozguc H. Necrotizing soft tissue infections: APACHE II score, dissemination, and survival. World J Surg 2007;31:1858-62. CrossRef

13. Laor E, Palmer LS, Tolia BM, Reid RE, Winter HI. Outcome prediction in patients with Fournier's gangrene. J Urol 1995;154:89-92. CrossRef

14. Gürdal M, Yücebas E, Tekin A, Beysel M, Aslan R, Sengör F. Predisposing factors and treatment outcome in Fournier's gangrene. Analysis of 28 cases. Urol Int 2003;70:286-90. CrossRef

15. Czymek R, Frank P, Limmer S, Schmidt A, Jungbluth T, Roblick U, et al. Fournier's gangrene: is the female gender a risk factor? Langenbecks Arch Surg 2010;395:173-80. CrossRef

16. Kabay S, Yucel M, Yaylak F, Algin MC, Hacioglu A, Kabay B, et al. The clinical features of Fournier's gangrene and the predictivity of the Fournier's Gangrene Severity Index on the outcomes. Int Urol Nephrol 2008;40:997-1004. CrossRef

17. Sugihara T, Yasunaga H, Horiguchi H, Fujimura T, Ohe K, Matsuda S, et al. Impact of surgical intervention timing on the case fatality rate for Fournier's gangrene: an analysis of 379 cases. BJU Int 2012;110(11 Pt C):E1096-100. CrossRef

18. Korkut M, Içöz G, Dayangaç M, Akgün E, Yeniay L, Erdoğan O, et al. Outcome analysis in patients with Fournier's gangrene: report of 45 cases. Dis Colon Rectum 2003;46:649-52. CrossRef

19. Sorensen MD, Krieger JN, Rivara FP, Klein MB, Wessells H. Fournier's gangrene: management and mortality predictors in a population based study. J Urol 2009;182:2742-7. CrossRef

20. Ozturk E, Sonmez Y, Yilmazlar T. What are the indications for a stoma in Fournier's gangrene? Colorectal Dis 2011;13:1044-7. CrossRef

21. Ozturk E, Ozguc H, Yilmazlar T. The use of vacuum assisted closure therapy in the management of Fournier's gangrene. Am J Surg 2009; 197:660-5. CrossRef

22. Ersay A, Yilmaz G, Akgun Y, Celik Y. Factors affecting mortality of Fournier's gangrene: review of 70 patients. ANZ J Surg 2007;77:43-8.

23. Roghmann F, von Bodman C, Löppenberg B, Hinkel A, Palisaar J, Noldus J. Is there a need for the Fournier's gangrene severity index? Comparison of scoring systems for outcome prediction in patients with Fournier's gangrene. BJU Int 2012;110:1359-65. CrossRef 


\section{KLINIK ÇALIŞMA - ÖZET}

\section{Fournier gangreni: 120 olgunun değerlendirmesi ve mortalite prediktörleri}

Dr. Tuncay Yılmazlar, ${ }^{1}$ Dr. Özgen Işık, ${ }^{1}$ Dr. Ersin Öztürk, ${ }^{1}$ Dr. Ali Özer, ${ }^{1}$ Dr. Barış Gülcü, ${ }^{1}$ Dr. İlker Ercan ${ }^{2}$

${ }^{1}$ Uludağ Üniversitesi Tıp Fakültesi, Genel Cerrahi Anabilim Dalı, Bursa;

2Uludağ Üniversitesi Tıp Fakültesi, Biyoistatistik Anabilim Dalı, Bursa

AMAÇ: Fournier gangreni (FG) acil ve agresif debridman gerektiren, yıkıcı ve potansiyel ölümcül bir hastalıktır. Bu çalışmanın amacı FG için mortalite prediktörlerini geniş bir kohortta araştırmaktır.

GEREÇ VE YÖNTEM: Fournier gangreni hastalarının ileriye yönelik olarak kaydedilmiş verileri derlendi. Demografik veriler, semptom süresi, Uludağ Fournier Gangreni Şiddet Skoru (UFGSI), yandaş hastalıklar [özellikle diabetes mellitus (DM)], etiyoloji, debridman sayısı, stoma gereksinimi, yoğun bakım ve hastane yatış süresi, morbidite ve mortalite oranları değerlendirildi. Multivaryans analiz ile mortaliteye etkili faktörler belirlendi.

BULGULAR: Median yaşı 58 (22-85) olan 120 hasta (8I erkek) çalışmaya alındı. Median UFGSI skoru 9'du (I-30). Altmış dokuz hastada (\%57.5) DM vardı. FG 59 hastada perianal, 52 hastada ürogenital ve 9 hastada cilt kaynaklıydı. Median debridman sayısı 3'tü (I-I2) ve 3 I hastada stoma açıldı, 48 hasta yoğun bakımda takip edilirken 25 hastada mekanik ventilasyon desteği gerekti. Toplam mortalite oranı \%20.8'di. Multivaryans analizde UFGSI tek mortalite prediktörü olarak saptandı $(\mathrm{p}=0.00 \mathrm{I})$. UFGSI 9 veya daha yüksek olan hastalarda mortalite oranı I3.64 kez daha sıktı.

TARTIŞMA: Fournier gangreni acil cerrahi gerektiren ölümcül bir hastalıktır. UFGSI FG hastalarında mortalitenin etkin bir prediktörüdür. Anahtar sözcükler: Fournier gangreni; mortalite; şiddet skoru.

Ulus Travma Acil Cerr Derg 2014;20(5):333-337 doi: 10.5505/tites.20I4.06870 